\title{
A Study of Students Perceived Computer Knowledge
}

\author{
Mark Ciampa \\ Dept. of Information Systems, Western Kentucky University \\ 1906 College Heights Blvd \#21058, Bowling Green, KY 42101
}

Tel: 1-270-745-8728Ｅ-mail: mark.ciampa@wku.edu

Accepted: Feb 24, 2013 Published: April 04, 2013

Doi:10.5296/ijld.v3i2.3355 URL: http://dx.doi.org/10.5296/ijld.v3i2.3355

\begin{abstract}
Whereas several studies have examined a student's perceived computer skills or objective computer knowledge, few studies have investigated a student's perceived computer knowledge. Even though it may not always be accurate, a student's perceptions of their computer knowledge can nevertheless still be beneficial. This information may be helpful in revealing any predictors that can be identified for student success and can also be used to provide student support for achieving technological mastery. This study looks at the computer knowledge students see themselves possessing, with the purpose of determining if there are any associations between the perceived knowledge and the student's gender, age, use and knowledge of technology, employment status, and technology owned. The results of the study seem to indicate that there are a limited number of associations between gender and a student's knowledge of specific computer topics but no significant associations exist between knowledge and age, current employment status, use/knowledge of technology, and technology owned.
\end{abstract}

Keywords: student perceived computer knowledge, computer literacy

\section{Introduction}

Technology is ubiquitous on college campuses today (Hawkings \& Oblinger, 2006). However, the overall level of student technology competency is not considered high. Many students who espouse high confidence in their digital literacy is only because they have successfully mastered a small portion of the technology available to them (Hargittai, 2005), such as using an MP3 player or sending a text message with a cellular telephone. Students often perceive themselves as better prepared in technology than they actually are (Marakas, Johnson, \& Clay, 2007).

Yet a student's perceptions of their computer knowledge - even though they may not be entirely accurate - can nevertheless still be beneficial. By examining perceived computer knowledge it can reveal what areas students think they know about computer technology. This information may be helpful in uncovering what--if any--predictors can be identified for student success in a college-level introduction to computers course for colleges. It can also be used to develop strategies to assess technology competencies of beginning college students and then provide student support for achieving technological mastery. 


\section{Literature Review}

Students who are leaving high schools and entering institutes of higher education are a digitally literate generation (Kilcoyne, et al., 2009). Jones called these students, born between 1982 and 1991, the "Net generation" (2007). Not only are they digitally literate when they enter college but these students also have a heightened interest in technology during their college career. In one study over a ten year time period graduates reported that the topic that had largest increase in perceived importance for them was computer literacy (Coll \& Zegwaard, 2006). Because of these graduates' perceptions of the importance of technology this has dramatically affected the attention given to it during their undergraduate preparation (Hanson, Hanson, Perez-Mira, Kilcoyne, \& Champion, 2011).

In order to support this heighted student interest in technology, McDonald (2004) recommended that campuses incorporate flexible testing tools--such as an Internet-based, interactive skills test--to measure basic computer skills. Banister and Vannatta (2006) found that various methodologies have been used to measure a student's computer competencies; however, there are no standardized scales for assessing competence. They suggested that colleges develop strategies to assess technology competencies of beginning college students and then move beyond such assessments to provide student support for achieving technological competencies.

Numerous research studies have been conducted regarding students and computer literacy. Hindi, Miller, and Wenger (2002) investigated students' perceptions of computer literacy skills that they developed prior to enrolling in a university in order to develop recommendations for teaching a college-level computer course. Stephens developed a decision support system built around a scale that can be implemented to perform training needs assessment. The system can determine who requires training and which training mode is most appropriate (Stephens, 2005). Other studies have been conducted that looked at identifying predictors for student success in a college-level introduction to computers course (Baxter, Hungerford, \& Helms, 2011). Levine and Donitsa-Schmidt (1998) found that research in the area of educational computing measured different student abilities and attitudes focused on the following four crucial factors: computer-related attitudes, the amount and nature of prior computer experience, computer knowledge, and belief in their own ability to operate successfully with computers or self-efficacy (Baxter, Hungerford, \& Helms, 2011). These latter two factors - computer knowledge and self-efficacy_have been widely studied.

\subsection{Computer Self-Efficacy}

Self-efficacy is a social cognitive construct popularized in the 1970s. It was later formally defined by Bandura as "people's judgments of their capabilities to organize and execute courses of action required to attain designated types of performances" (Bandura, 1986, p. 39). Bandura also said that beliefs about efficacy may influence a person's choice of activities, the level of effort a person is willing to expend, their persistence in the presence of difficulties, and their overall performance (1986). Hasan and Jafar (2004) defined self-efficacy as an individual's judgment of their own capabilities to organize and execute courses of action to attain designated performance. Kinzie, Delcourt, and Powers (1994) described self-efficacy as an individual's confidence in his or her ability, which may impact the performance of tasks.

Computer self-efficacy (CSE) is derived from self-efficacy in general (Bandura, 1997) and is defined as "a judgment of one's ability to use a computer" (Compeau \& Higgins, 1995, p. 192). CSE refers to an individual's judgments of their capabilities to use computers in diverse situations (Marakas, Yi, \& Johnson, 1998). Hasan (2003) described CSE as a judgment of 
success or skill in performing a well-defined computing task using a particular application, such as word processing, spreadsheet, or database programs. Marakas, Yi, and Johnson separated task-specific measures of CSE from general computer self-efficacy and defined these task-specific measures as "an individual's perception of efficacy in performing specific computer-related tasks within the domain of general computing" (Marakas, Yi, \& Johnson, 1998, p. 128). CSE has been found to be a determinant of computer-related ability and the use of computers (Hasan, 2003). Divaris, Polychronopoulou, and Mattheos (2007) stated that an accurate assessment of the computer skills of students is a prerequisite for success in other areas, including online learning.

CSE has been studied in depth by a number of researchers, including Agarwal, Sambamurthy, and Stair (2000), Marakas, Johnson, and Clay (2007), and Marakas, Yi, and Johnson (1998). Qutami and Abu-Jaber (1997) examined gender and the user's cognitive learning styles to self-efficacy in computer skills. Computer use and personal interest had a direct and significant effect on CSE (Hsu \& Huang, 2006). Goh, Ogan, Ahuja, Herring, and Robinson (2007) looked at the relationship between CSE and mentoring as well as the gender of students and their mentors. Busch's initial study (1995) examined gender differences in CSE and attitudes toward computers while his follow-up study looked at group composition and cooperation (1996). Stephens said that users with low CSE will avoid interacting with computer technology when given a choice (2005). Heinrichs and Lim (2010) examined users' perceived functional skills and competency in word processing and presentation tools. Cassidy and Eachus (2002) created a computer user self-efficacy scale, in part because CSE has been identified as a success factor for the completion of computing tasks. They noted that a significant positive correlation between CSE and computer experience could be established, and familiarity with computer software was a significant predictor of CSE while computer ownership and training increased efficacy.

Those users with a high CSE tend to participate in computer-related activities and expect success in these activities; they also persist and use effective coping mechanisms when they encounter problems, and exhibit higher levels of performance than individuals with lower CSE (Compeau, Higgins, \& Huff, 1999). CSE captures the competence and confidence that management information systems professors hope to provide to their students (Karsen \& Roth, 1998). Users gain CSE from several different sources: their personal successes and failures, observing the successes and failures of peers, and encouragement (Bandura, 1997). CSE is dynamic and changes as users gain new information and computer-related experiences (Gist \& Mitchell, 1992). Students' CSE typically is influenced by both prior coursework and personal experiences. However, Karsten and Roth (1998) stated that not just the experience changes a user's CSE but it is the kind of experience. CSE has been shown to influence an individual's choice to engage in a technology task and the effort expended to accomplish it (Hanson, Kilcoyne, Perez-Mira, Hanson, \& Champion, 2011).

A student's CSE in relation to their first computer course has been extensively studied. In a study of CSE among high school students no statistically significant differences based on gender were detected in either pre-tests or post-tests (Mayall, 2008). Shiue (2003) looked at the effect of cognitive learning styles and prior computer experience on students' CSE among those who were enrolled in basic computer literacy courses. Using pre-tests and post-tests Albion (2001) stated that a students' CSE could be affected by whether or not they owned their own computer. Introductory information systems course-related factors were also studied as indicators of CSE (Karsen \& Roth, 1998), while Houle (1996) looked at student differences and demographics. First-semester college student's CSE of computer application skills were 
also examined and revealed that students self-reported stronger than moderate skills in word processing, file management, presentation applications, and spreadsheet applications (DuFrene, Clipson, \& Wilson, 2010).

While some educators concluded that students are becoming progressively more computer literate, many researchers have found a significant discrepancy between their perception of computer skill levels and the reality of lower competence (Hanson, Kilcoyne, Perez-Mira, Hanson, \& Champion, 2011). Students believe they are computer literate (Wilkinson, 2006). Grant, Malloy, \& Murphy compared students' CSE ratings with their actual performance on an author-developed computer skills test. Their study demonstrated a gap between what students perceived as their computing skills and their actual assessed skills (Grant, Malloy, \& Murphy, 2009). Kilcoyne et al looked at student confidence in the mastery of technology to determine if a student's general confidence in their mastery is representative of their knowledge. When students averaged only 42 percent on the test administered the researchers concluded that students greatly overestimated their mastery of technology (Kilcoyne, et al., 2009). Another study examined the discrepancies between students' perceptions of their digital skills compared to their actual performance on business computer software applications. These two factors were compared to their identified learning styles (Hanson, Kilcoyne, Perez-Mira, Hanson, \& Champion, 2011).

\subsection{Computer Knowledge}

In addition to CSE the computer knowledge of students has also been widely studied. Davis and Davis surveyed students in technology teacher education and training to determine their self-perception of their competency in five constructs composed of 43 elements related to personal computer knowledge. Their study revealed that although gender was not a factor there was a significant difference between the students' perceived competencies based on age range: students whose age was 35 old or younger perceived a higher level of competence when compared to older students (Davis \& Davis, 2007). Another study attempted to determine the attitudes of students concerning the importance of protecting information assets and their knowledge of general behavioral, computer-based, and wireless security actions that can be taken to help protect computers and information assets (Oswalt, Lisenby, \& Johnson, 2009).

Divaris, Polychronopoulou, and Mattheos (2007) studied the computer knowledge of post-graduate students and found that competence scores were normally distributed but that gender and e-mail usage were significant predictors of computer literacy. Wilkinson found significant differences between the computer knowledge of Caucasian students and ethnic minorities (2006). Another study compared self-assessment to results on objective tests and found that students significantly over-estimated their level of computer competence. However, the researchers concluded that students' home and high school computer use did not affect the results (Ballantine, Larres, \& Oyelere, 2007).

Webster examined the relationship between computer literacy scores and computer use confidence both before an introduction to computers course began and at the end of the course in order to assess gains in computer literacy and usage confidence. The research revealed that prior computer classes and computer usage positively influenced literacy scores and confidence, and that using the computer for e-mail also influenced confidence scores (Webster, 2004). Messineo and DeOllos (2005) discovered differences by gender and race/ethnicity. Some studies found that males reported higher results than females (Cassidy \& Eachus, 2002).

Many studies that examined a student's computer knowledge used an objective assessment instrument to determine what the students know. These instruments may be divided into two 
categories. The first category was instruments that are specifically designed to measure computer skills. In one study computer knowledge of students was measured by scores on the exam portion of the Computer Experiences and Knowledge Inventory or CEKI (Smith, Villareal, Akers, \& Haygood, 2004).

The second category used scores from instruments such as mathematical and verbal scores from the SAT college admission exam or Turkey's National Student Selection Examination or SSE (Varank I. , 2007). However, results from these studies of computer knowledge based on standardized tests seem inconclusive. One study indicated that the SAT was an important factor in reliably predicting major GPA in computer science programs (Shoemaker, 1986) while another study stated that SAT math scores could be used to predict potential successful computer science students (Campbell \& McCabe, 1984). Sorge and Wark (1984) said that these scores also impacted a student's decisions to continue their education in computer science programs. However, research by Fan and Li (2002) indicated that the college entrance exam math score negatively correlated to performance of students' introductory computer science classes and overall class work for the computer science programs.

\section{The Need for This Study}

CSE studies examine a student's perceived computer skills and not computer knowledge. Most computer knowledge studies examine a student's objective computer knowledge. Yet one element missing is to examine a student's perceived computer knowledge instead of perceived skills or objective knowledge.

In addition, several CSE studies make assumptions regarding students' knowledge and skills. For example, in one study a one-page questionnaire consisting of 13 items was designed by the authors to survey students about their perceptions of their own computer skills in seven career-oriented computer applications (file management, word processing, spreadsheets, presentations design, database applications, web page development, and computer programming). Students were asked to rate their level of skill in the seven computer skill areas on a Likert scale of 0-5, with 0 being "never used," 1 being "low skill," and 5 being "high skill" (Hanson, Kilcoyne, Perez-Mira, Hanson, \& Champion, 2011). However, there was not a meaningful procedure for students who had no knowledge of the topic to respond (a student could answer "never used" but this gives no indication of their knowledge of the topic).

By examining perceived computer knowledge it can reveal what areas students think they know about computer technology. This information may be helpful in identifying what--if any--predictors can be identified for student success in a college-level introduction to computers course for colleges. It can also be used to develop strategies to assess technology competencies of beginning college students and then move to provide student support for achieving technological mastery.

\section{The Study}

Over a two-semester period of time 479 students were surveyed at an accredited mid-south regional university. The surveys were conducted either the first or second day of the students' introduction to computer course prior to any specific technology training or instruction.

The survey was broken into five categories of technology: security, word processing, database, Internet, and general computer technology. For each of these five categories students were asked five questions about a specific technology within that category, for a total of 25 questions. Each question was reviewed in advance by faculty currently teaching these courses. Table 1 lists the categories and questions. 
Table 1. Categories and Questions

\begin{tabular}{|c|c|c|c|c|c|}
\hline Category & Question 1 & Question 2 & Question 3 & Question 4 & Question 5 \\
\hline Security & $\begin{array}{l}\text { Using } \\
\text { anti-virus } \\
\text { software } \\
\end{array}$ & $\begin{array}{l}\text { Using } \\
\text { firewall }\end{array}$ & $\begin{array}{l}\text { Securing } \\
\text { wireless } \\
\text { networks }\end{array}$ & $\begin{array}{l}\text { Using spam } \\
\text { filers }\end{array}$ & $\begin{array}{l}\text { Protecting } \\
\text { yourself from } \\
\text { phishing }\end{array}$ \\
\hline $\begin{array}{l}\text { Word } \\
\text { Processing }\end{array}$ & $\begin{array}{lr}\text { How to set } \\
\text { the margins } \\
\text { in } \\
\text { document }\end{array}$ & $\begin{array}{l}\text { How to } \\
\text { include } \\
\text { references in } \\
\text { a document }\end{array}$ & $\begin{array}{l}\text { How to } \\
\text { insert a } \\
\text { comment in } \\
\text { a document }\end{array}$ & $\begin{array}{l}\text { How to } \\
\text { create a } \\
\text { macro for a } \\
\text { document }\end{array}$ & $\begin{array}{l}\text { How to } \\
\text { create a table } \\
\text { in a } \\
\text { document }\end{array}$ \\
\hline Database & $\begin{array}{lr}\text { How } & \text { to } \\
\text { create } & \text { a } \\
\text { relational } & \\
\text { database } & \\
\end{array}$ & $\begin{array}{l}\text { How to create } \\
\text { a table }\end{array}$ & $\begin{array}{l}\text { How to } \\
\text { create } \\
\text { reports from } \\
\text { a database }\end{array}$ & $\begin{array}{l}\text { How to query } \\
\text { a database }\end{array}$ & $\begin{array}{l}\text { How to set } \\
\text { security on a } \\
\text { database }\end{array}$ \\
\hline Internet & $\begin{array}{l}\text { How to run a } \\
\text { complex } \\
\text { search }\end{array}$ & $\begin{array}{l}\text { How } \\
\text { computers } \\
\text { communicate }\end{array}$ & $\begin{array}{l}\text { How to } \\
\text { configure a } \\
\text { computer to } \\
\text { connect to } \\
\text { the Internet } \\
\end{array}$ & $\begin{array}{l}\text { How to } \\
\text { verify the } \\
\text { information } \\
\text { you find on } \\
\text { the Internet }\end{array}$ & $\begin{array}{l}\text { How to } \\
\text { configure a } \\
\text { web browser }\end{array}$ \\
\hline $\begin{array}{l}\text { General } \\
\text { Computer } \\
\text { Technology }\end{array}$ & $\begin{array}{l}\text { How to copy } \\
\text { information } \\
\text { from one } \\
\text { application to } \\
\text { another }\end{array}$ & $\begin{array}{l}\text { How to } \\
\text { organize your } \\
\text { files }\end{array}$ & $\begin{array}{l}\text { How to scan } \\
\text { your } \\
\text { computer for } \\
\text { malware }\end{array}$ & $\begin{array}{ll}\text { How } & \text { to } \\
\text { create } & \\
\text { backups } & \end{array}$ & $\begin{array}{l}\text { How to } \\
\text { embed } \\
\text { graphics, } \\
\text { video, or } \\
\text { sound in } \\
\text { other } \\
\text { software } \\
\text { applications }\end{array}$ \\
\hline
\end{tabular}

Students were asked to rate their answers to the questions on a 5-point Likert scale: "Very Important", "Important", "Neutral", "Somewhat Unimportant", and "Unimportant". In addition, another option for each question was "Unfamiliar with Topic". For this study the focus was exclusively upon what topics students indicated that they did not have knowledge of ("Unfamiliar with Topic") compared with those that they did have knowledge of. This allowed for an examination of perceived computer knowledge. Students were also asked to provide demographic information that could be used to determine if there were associations between knowledge and five areas of the student's lives: sex, age, use/knowledge of technology, employment status, and technology owned.

\section{Results}

Initially, a series of descriptive statistics were conducted on these data in order to better describe this sample. First, the following Table 2 summarizes respondents with regard to sex. As shown, this sample had a slight majority of males.

Table 2. Descriptive Statistics: Sex

\begin{tabular}{|l|l|l|}
\hline Category & N & Percentage \\
\hline Male & 238 & $50.5 \%$ \\
\hline Female & 233 & $49.5 \%$ \\
\hline
\end{tabular}


Next, the following Table 3 summarizes respondents with regard to current employment. As shown, a slight majority of the sample was found to be not currently employed, with a slight minority indicating current employment.

Table 3. Descriptive Statistics: Employed

\begin{tabular}{|l|l|l|}
\hline Category & N & Percentage \\
\hline Yes & 224 & $48.1 \%$ \\
\hline No & 242 & $51.9 \%$ \\
\hline
\end{tabular}

With regard to age, the mean age among this sample was found to be 20.91 years (SD $=3.74$ years). Additionally, the youngest respondent was found to be 18 years of age, with the oldest respondent being 53 years old.

A series of analyses were conducted in order to determine the extent of the association between familiarity/unfamiliarity and these same items with the measures of sex, age, use/knowledge of technology, employment status, and technology owned.

Table 4 summarizes the results of the analysis conducted focusing upon the association between respondent sex and familiarity/unfamiliarity. In some cases, the analysis could not be performed due to a lack of variation in the measures of important/unimportance. Significant associations were found between gender and scanning for malware, using a firewall, protection from phishing, creating a macro, creating formulas, using functions, using absolute addressing, protecting a worksheet, creating a relational database, and querying a database. In all cases, females were significantly more likely to state that they were unfamiliar with these tasks as compared with male respondents.

Table 4. Unfamiliarity Measures: Chi-Square Analyses: Sex

\begin{tabular}{|l|l|l|}
\hline Measure & Chi-Square (df) & $\mathrm{p}$ \\
\hline General Computer Topics & \multicolumn{2}{|l|}{} \\
\hline Copy Information & - & - \\
\hline Organize Files & - & - \\
\hline Scan for Malware & $6.694(1)$ & .010 \\
\hline Create Backups & $.001(1)$ & .975 \\
\hline Install Software & - & - \\
\hline Embed Multimedia & $1.898(1)$ & .168 \\
\hline Internet Topics & \multicolumn{2}{|l}{} \\
\hline Run a Complex Search & $.215(1)$ & .643 \\
\hline
\end{tabular}




\begin{tabular}{|c|c|c|}
\hline $\begin{array}{l}\text { How } \\
\text { Communicate }\end{array}$ & $3.085(1)$ & .079 \\
\hline Connect to the Internet & $2.026(1)$ & .155 \\
\hline Verify Information & $1.015(1)$ & .314 \\
\hline Configure a Web Browser & $1.046(1)$ & .306 \\
\hline \multicolumn{3}{|l|}{ Security } \\
\hline Using Antivirus Software & $1.033(1)$ & .310 \\
\hline Using a Firewall & $4.131(1)$ & .042 \\
\hline Securing Wireless Networks & $2.069(1)$ & .150 \\
\hline Using Spam Filters & $.234(1)$ & .629 \\
\hline Protection from Phishing & $7.308(1)$ & .007 \\
\hline Creating a Strong Password & $1.033(1)$ & .310 \\
\hline \multicolumn{3}{|l|}{ Word Processing } \\
\hline \multicolumn{3}{|l|}{ Set the Margins } \\
\hline \multicolumn{3}{|l|}{ Include References } \\
\hline Insert a Comment & $.639(1)$ & .405 \\
\hline Create a Macro & $13.061(1)$ & $<.001$ \\
\hline \multicolumn{3}{|l|}{ Create a Table } \\
\hline \multicolumn{3}{|l|}{ Spreadsheet } \\
\hline Create Formulas & $4.139(1)$ & .042 \\
\hline Use Functions & $6.235(1)$ & .013 \\
\hline Use Absolute Addressing & $10.667(1)$ & .001 \\
\hline Protect a Worksheet & $5.743(1)$ & .017 \\
\hline Apply Different Formulas & $1.724(1)$ & .189 \\
\hline \multicolumn{3}{|l|}{ Database } \\
\hline Create a Relational Database & $7.782(1)$ & .005 \\
\hline Create a Table & $.093(1)$ & .761 \\
\hline
\end{tabular}




\begin{tabular}{|l|l|l|}
\hline $\begin{array}{l}\text { Create Reports from a } \\
\text { Database }\end{array}$ & $.548(1)$ & .459 \\
\hline Query a Database & $8.404(1)$ & .004 \\
\hline Set Security on a Database & $3.844(1)$ & .050 \\
\hline
\end{tabular}

A series of chi-square analyses were conducted between technology owned and these measures of familiarity/unfamiliarity. The results of these six sets of analyses are summarized in Table 5, with the probability levels associated with each analysis being presented. Ownership of a Windows PC was found to be significantly associated with inserting a comment, with individuals who owned a Windows PC being significantly less likely to be unfamiliar with this task. No other significant results were found within this set of analyses.

Table 5. Unfamiliarity Measures: Chi-Square Analyses: Technology Owned

\begin{tabular}{|c|c|c|c|c|c|c|}
\hline Measure & Windows PC & Mac & Smartphone & Tablet & Ebook & None \\
\hline \multicolumn{7}{|c|}{ General Computer Topics } \\
\hline $\begin{array}{l}\text { Copy } \\
\text { Information }\end{array}$ & - & - & - & - & - & - \\
\hline Organize Files & - & - & - & - & - & - \\
\hline $\begin{array}{l}\text { Scan } \quad \text { for } \\
\text { Malware }\end{array}$ & .217 & .623 & .272 & .889 & .090 & .644 \\
\hline Create Backups & .142 & .676 & .166 & .258 & .478 & .779 \\
\hline Install Software & - & - & - & - & - & - \\
\hline $\begin{array}{l}\text { Embed } \\
\text { Multimedia }\end{array}$ & .201 & .184 & .266 & .302 & .518 & .798 \\
\hline \multicolumn{7}{|l|}{ Internet Topics } \\
\hline $\begin{array}{l}\text { Run a Complex } \\
\text { Search }\end{array}$ & .807 & .752 & .265 & .877 & .301 & .797 \\
\hline $\begin{array}{l}\text { How Computers } \\
\text { Communicate }\end{array}$ & .092 & .111 & .693 & .424 & .614 & .842 \\
\hline $\begin{array}{l}\text { Connect to the } \\
\text { Internet }\end{array}$ & .417 & .398 & .876 & .515 & .681 & .871 \\
\hline $\begin{array}{l}\text { Verify } \\
\text { Information }\end{array}$ & .569 & .549 & .267 & .649 & .771 & .909 \\
\hline $\begin{array}{l}\text { Configure a Web } \\
\text { Browser }\end{array}$ & .872 & .303 & .997 & .164 & .380 & .729 \\
\hline
\end{tabular}




\begin{tabular}{|c|c|c|c|c|c|c|}
\hline \multicolumn{7}{|l|}{ Security } \\
\hline $\begin{array}{l}\text { Using Antivirus } \\
\text { Software }\end{array}$ & .573 & .558 & .370 & .645 & .773 & .909 \\
\hline Using a Firewall & .931 & .392 & .319 & .892 & .289 & .676 \\
\hline $\begin{array}{l}\text { Securing } \\
\text { Wireless } \\
\text { Networks }\end{array}$ & .425 & .407 & .875 & .515 & .683 & .872 \\
\hline $\begin{array}{l}\text { Using } \quad \text { Spam } \\
\text { Filters }\end{array}$ & .832 & .775 & .268 & .182 & .517 & .798 \\
\hline $\begin{array}{l}\text { Protection from } \\
\text { Phishing }\end{array}$ & .507 & .415 & .099 & .930 & .798 & .584 \\
\hline $\begin{array}{l}\text { Creating a } \\
\text { Strong Password }\end{array}$ & .573 & .558 & .370 & .645 & .773 & .909 \\
\hline \multicolumn{7}{|l|}{ Word Processing } \\
\hline Set the Margins & - & - & - & - & - & - \\
\hline $\begin{array}{l}\text { Include } \\
\text { References }\end{array}$ & - & - & - & - & - & - \\
\hline $\begin{array}{l}\text { Insert } \\
\text { Comment }\end{array}$ & .017 & .183 & .777 & .257 & .482 & .778 \\
\hline Create a Macro & .203 & .866 & .238 & .446 & .958 & .382 \\
\hline Create a Table & - & - & - & - & - & - \\
\hline \multicolumn{7}{|l|}{ Spreadsheet } \\
\hline Create Formulas & .978 & .967 & .827 & .356 & .563 & .820 \\
\hline Use Functions & .609 & .676 & .797 & .961 & .402 & .779 \\
\hline $\begin{array}{l}\text { Use Absolute } \\
\text { Addressing }\end{array}$ & .167 & .529 & .230 & .872 & .991 & .374 \\
\hline $\begin{array}{l}\text { Protect } \\
\text { Worksheet }\end{array}$ & .593 & .433 & .552 & .272 & .526 & .536 \\
\hline $\begin{array}{l}\text { Apply Different } \\
\text { Formulas }\end{array}$ & .674 & .669 & .765 & .537 & .363 & .716 \\
\hline Database & & & & & & \\
\hline
\end{tabular}




\begin{tabular}{|l|l|l|l|l|l|l|}
\hline $\begin{array}{l}\text { Create } \\
\text { Relational } \\
\text { Database }\end{array}$ & .092 & .272 & .728 & .471 & .951 & .465 \\
\hline Create a Table & .532 & .610 & .171 & .197 & .383 & .731 \\
\hline $\begin{array}{l}\text { Create Reports } \\
\text { from a Database }\end{array}$ & .372 & .304 & .237 & .849 & .201 & .613 \\
\hline $\begin{array}{l}\text { Query a } \\
\text { Database }\end{array}$ & .230 & .273 & .814 & .257 & .613 & .390 \\
\hline $\begin{array}{l}\text { Set Security on a } \\
\text { Database }\end{array}$ & .144 & .739 & .828 & .894 & .371 & .518 \\
\hline
\end{tabular}

A series of independent-samples t-tests were conducted in order to determine whether there were significant associations between familiarity/unfamiliarity and age. Initially, Levene's test for the equality of variances was conducted in order to test the assumption of the independent-samples t-test that the variances in the dependent variable are not significantly different based upon levels of the independent variable. This test was found to be significant, indicating a violation of this assumption in one case, which required the use of a modified equation for the independent-samples t-test which does not incorporate the assumption of equal variances. The results of these independent-sample t-tests found no significant associations between age and familiarity/unfamiliarity with regard to these items.

A series of chi-square analyses were also conducted in order to determine the association between familiarity/unfamiliarity of these items and current employment status. These results indicate no significant associations between current employment status and familiarity/unfamiliarity with these items.

The final set of analyses conducted consisted of a series of Mann-Whitney U tests which serve the purpose of determining whether significant associations exist between the use/knowledge of technology and familiarity/unfamiliarity with these items. No significant associations were found based upon these results.

\section{Conclusion}

Whereas CSE examine a student's perceived computer skills and computer knowledge studies examine a student's objective computer knowledge, this current study examined a student's perceived computer knowledge instead of perceived skills or objective knowledge. For this study the student's perceived computer knowledge was used to determine if there were associations between that perceived computer knowledge and sex, age, use/knowledge of technology, employment status, and technology owned.

The results of the study seem to indicate that there are no significant associations found between familiarity/unfamiliarity and age, current employment status, and use/knowledge of technology. Only a limited number of associations between sex and familiarity/unfamiliarity were found on specific items. These include scanning for malware, using a firewall, protection from phishing, creating a macro, creating formulas, using functions, using absolute addressing, protecting a worksheet, creating a relational database, and querying a database. In 
all cases, females were significantly more likely to state that they were unfamiliar with these tasks as compared with male respondents.

Building upon this current study there are additional areas of research that may be explored. Additional categories of technology topics beyond those used in this study can be added in order to that determine a students' familiarity with those topics. In addition, the discrepancy between male and female responses in specific categories may warrant addition study.

\section{References}

Agarwal, R., Sambamurthy, V., \& Stair, R. (2000). Research report: The evolving relationship between general and specific computer self-efficacy-an empirical assessment. Information Systems Research, 11(4), 418-430.

Albion, P. (2001). Some factors in the development of self-efficacy beliefs for computer use among teacher education. Journal of Technology and Teacher Education, 9(3), 321-334.

Ballantine, J., Larres, P., \& Oyelere, P. (2007). Computer usage and the validity of self-assessed computer competence among first-year business students. Computers and Education, 49(4), 976-990.

Bandura, A. (1986). Social foundations of thought and action: A social cognitive theory. Englewood Cliffs, NJ: Prentice Hall.

Bandura, A. (1997). Self-efficacy: the exercise of control. New York, NY:: W. H. Freeman.

Banister, S., \& Vannatta, R. (2006). Beginning with a baseline: Insuring productive technology integration in teacher education. Journal of Technology and Teacher, 14(1), 209-235.

Baxter, J., Hungerford, B., \& Helms, M. (2011, June). Predicting success in the introduction to computers course: GPA vs. student's self-efficacy scores. Information Systems Education Journal, 9(2), 75-91.

Buche, M. D., \& Vician, C. (2007). A longitudinal investigation of the effects of computer anxiety on performance in a computing-intensive environment. Journal of Information Systems, 18(4), 415-423.

Busch, T. (1995). Gender differences in self-efficacy and attitudes towards computers. Journal of Educational Computing Research, 12(2), 147-159.

Busch, T. (1996). Gender, group composition, cooperation, and self-efficacy in computer studies. Journal of Educational Computing Research, 15(2), 125-138.

Cassidy, S., \& Eachus, P. (2002). Developing the computer user self-efficacy (CUSE) scale: Investigating the relationship between. Journal of Educational Computing Research, 26(2), 133-153.

Coll, R., \& Zegwaard, K. (2006). Perceptions of desirable graduate competencies for science and technology new graduates. Research in Science and Technological Education, 24(1), 29-58.

Compeau, D., \& Higgins, C. (1995). Computer self-efficacy: Development of a measure and initial test. MIS Quarterly, 19(2), 189-211.

Compeau, D., Higgins, C., \& Huff, S. (1999). Social cognitive theory and individual reactions to computing technology: A longitudinal study. MIS Quarterly, 23(2), 145-158.

Davis, J., \& Davis, H. (2007). Perceptions of career and technology and training and development students regarding basic personal computer knowledge and skills. College Student Journal, 41(1), 69-78.

Divaris, K., Polychronopoulou, A., \& Mattheos, N. (2007). An investigation of computer literacy and attitudes amongst Greek post-graduate dental students. European Journal of Dental Education, 11(3), 144-147. 
DuFrene, D., Clipson, T., \& Wilson, A. (2010). Measuring college students' technology self-efficacy. Association of Business Information Systems 2010 Refereed Proceedings, (pp. 13-20).

Gist, M., \& Mitchell, T. (1992). Self-efficacy: A theoretical analysis of its determinants and malleability. Academy of Management Review, 17(2), 183-211.

Goh, D., Ogan, C., Ahuja, M., Herring, S., \& Robinson, J. (2007). Being the same isn't enough: Impact of male and female mentors on computer self-efficacy of college students. Journal of Educational Computing Research, 37(1), 19-40.

Grant, D., Malloy, A., \& Murphy, M. (2009). A comparison of student perceptions of their computer skills to their actual abilities. Journal of Information Technology Education, $8,141-160$.

Hanson, B., Hanson, T., Perez-Mira, B., Kilcoyne, M., \& Champion, S. (2011). Walking out the door--do business graduates have the information technology skills they think they do? Association of Business Information Systems (pp. 1-6). Houston: ABIS.

Hanson, B., Kilcoyne, M., Perez-Mira, B., Hanson, T., \& Champion, S. (2011). Digital knowledge and application skills: A comparison study of entering freshman. Journal of Research in Business Information Systems, 4(4), 55-68.

Hargittai, E. (2005). Survey measures of web-oriented digital literacy. Socail Science Computer Review, 23(3), 371-379.

Hasan, B. (2003). The invluence of specific computer experiences on computer self-efficacy beliefs. Computers in Human Behavior, 19, 443-450.

Hasan, B., \& Jafar, M. (2004). An empirical examination of a model of computer learning performance. The Journal of Computer Information Systems, 44(4), 27-33.

Hawkings, B., \& Oblinger, D. (2006). The myth about the digital divide. EDUCAUSE Review, 41(4), 12-13.

Heinrichs, J., \& Lim, J. (2010). Information literacy and office tool competencies: A benchmark study. Journal of Education for Business, 85, 153-164.

Hindi, N., \& Wenger, J. (2002). Computer literacy: Implications for teaching a college-level course. Journal of Information Systems Education, 13(2), 143-151.

Houle, P. (1996). Toward understanding student differences in a computer skills course. Journal of Educational Computing Research, 15(1), 25-39.

Hsu, W., \& Huang, S. (2006). Determinants of computer self-efficacy - An examination of learning motivations and learning. Journal of Educational Computing Research, 35(3), 245-265.

Jennings, S., Wilson, S., Rucker, J., \& Braathen, S. (2007). Computer application employability skills. Association of Business Information 2007 Refereed Proceedings, (pp. 11-16).

Jones, D. (2007). Thinking critically about digital literacy: A learning sequence on pens, pages and pixels. Pedagogy, 7(2), 207-221.

Karsen, R., \& Roth, R. (1998). Computer self-efficacy: A practical indicator of student computer competency in introductory IS courses. Informing Science, 1(3), 61-68.

Karsten, R., \& Roth, R. (1998). The relationship of computer experience and computer self-efficacy to performance in introductory computer literacy courses. Journal of Research on Computing in Higher Education, 31(1), 14-24.

Kilcoyne, M., McDonald, J., Hanson, B., Champion, S., Garland, M., \& Maples, G. (2009). Can they really walk the talk? Association of Business Information Systems 2009 Refereed Proceedings (pp. 55-59). Oklahoma City, OK: ABIS.

Kinzie, M., Delcourt, M., \& Powers, S. (1994). Computer technologies: Attitudes and self-efficacy across undergraduate disciplines. Research in Higher Education, 35, 745-768. 
Kleen, B., \& Rodrigue, S. (2011). Computer literacy requirements in public universities in the southwestern region of the U.S.: A 2010 review. Association of Business Information Systems 2011 Refereed Proceedings (pp. 41-45). Houston: ABIS.

Kuhlemeier, J., \& Hemker, B. (2007). The impact of computer use at home on students' Internet skills. Computers and Education, 49(2), 460-480.

Marakas, G., Johnson, R., \& Clay, P. (2007). The evolving nature of the computer self-efficacy construct: An empirical investigation of measurement construction, validity, reliability, and stability over time. Journal of the Association for Information Systems, 8(1), 16-46.

Marakas, G., Johnson, R., \& Clay, P. (2007). The evolving nature of the computer self-efficacy construct: An empirical investigation of measurement construction, validity, reliability, and stability over time. Journal of Association for Information Systems, 8(1), 16-46.

Marakas, G., Yi, M., \& Johnson, R. (1998). The multilevel and multifaceted character of computer self-efficacy: Toward clarification of the construct and an integrative framework for research. Information Systems Research, 9(2), 126-163.

Mayall, J. (2008). Differences in gender based technology self-efficacy across academic levels. International Journal of Instruction, 35(2), 145-166.

McDonald, D. (2004). Computer literacy skills for computer information systems majors: A case study. Journal of Information Systems, 15(1), 19-33.

Messineo, M., \& DeOllos, I. (2005). Are we assuming too much? Exploring students' perceptions of their computer competence. College Teaching, 53(2), 50-55.

Oblinger, D., \& Hawkins, B. (2006). The myth about student competency. Educause Review, $41(2), 12-13$.

Oblinger, D., \& Oblinger, J. (2006). Is it age or IT: First steps toward understanding the net generation. CSLA Journal, 29(2), 8-16.

Oswalt, B., Lisenby, R., \& Johnson, S. (2009). Protecting information assets: Attitudes and actions of business students. Association of Business Information Systems (pp. 70-74). Oklahoma City: ABIS.

Qutami, Y., \& Abu-Jaber, M. (2997). Students' self-efficacy in computer skills as a function of gender and cognitive learning style at Sultan Qaboos University. International Journal of Instructional Media, 24(1), 63-74.

Shiue, Y. (2003). The effects of cognitive learning style and prior computer experience on Taiwanese college students' computer self-efficacy in computer literacy courses. Journal of Educational Technology Systems, 31(4), 393-410.

Skiba, D., \& Barton, A. (2006, May). Adapter your teaching to accomodate the net generation of learners. Online Journal of Issues in Nursing, 11(2), 15-25.

Stephens, P. (2005). A decision support system for computer literacy training at universities. The Journal of Computer Information, 46(2), 33-44.

Tien, F., \& Fu, T. (2008). The correlates of the digital divide and their impact on college student learning. Computers and Education, 50(1), 421-436.

Varank, I. (2007). Effectiveness of quantitative skills, qualitative skills, and gender in determining computer skills and attitudes: A causal analysis. The Clearing House, 81(2), 71-80.

Wilkinson, K. (2006). Student's computer literacy: Perception versus reality. Delta Pi Epsilon Journal, 48(2), 108-120. 